\title{
Late-onset congenital syphilis with unusual brain abnormalities
}

\author{
Sífilis congênita de início tardio com anormalidades encefálicas incomuns
}

Rodrigo Alencar e Silva', Camila Campelo', Clecio Godeiro-Junior ${ }^{1}$

A 17-year-old woman presented with ataxia, refractory epilepsy and progressive cognitive decline since the age of eight. A brain MRI showed white matter abnormalities and atrophy (Figures 1 and 2). Her mother had positive tests for syphilis in her prenatal screening, but had not received any treatment. In our patient, serum VDRL (1:16) and IgG-FTA-ABS

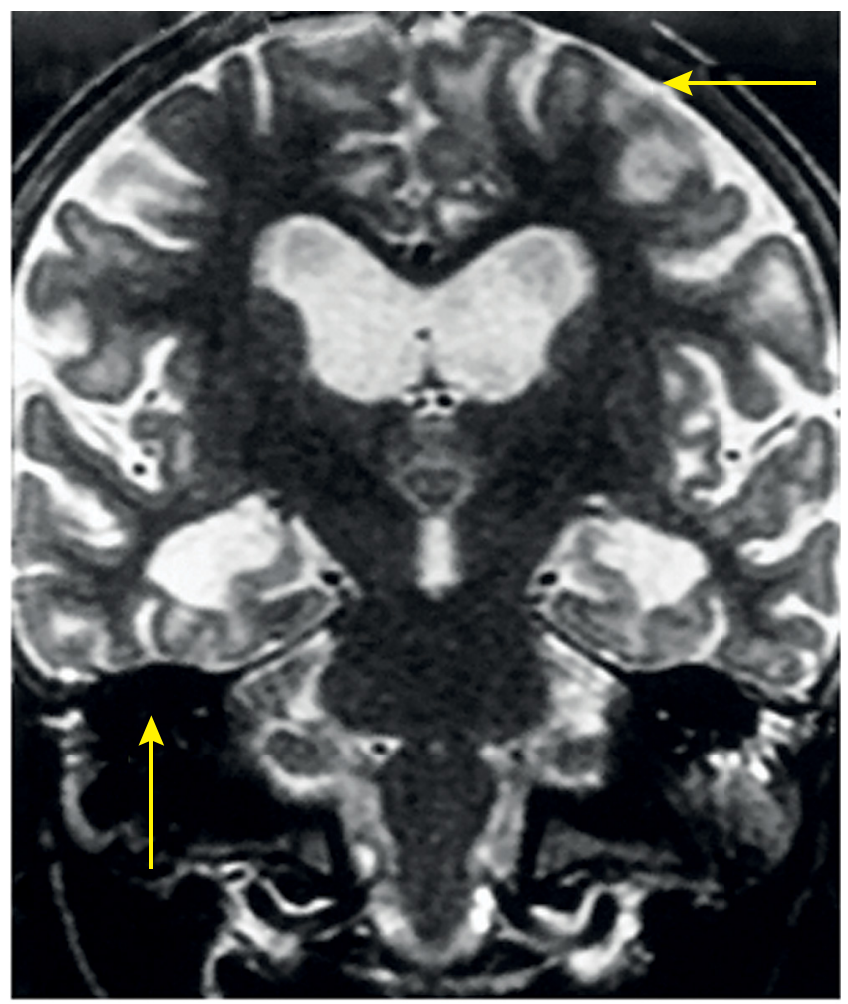

Figure 1. Coronal T2 MRI sequence: brain atrophy and hyperintensities of the temporal and frontal lobes were positive. Her cerebrospinal fluid showed a slight increase in protein level, negative VDRL and positive FTA-ABS tests. Our diagnosis was late congenital syphilis with atypical brain abnormalities. We should be aware of this disorder and include it in the differential diagnosis of subacute neurological syndromes with frontal and temporal lesions on brain $\mathrm{MRI}^{1,2}$..

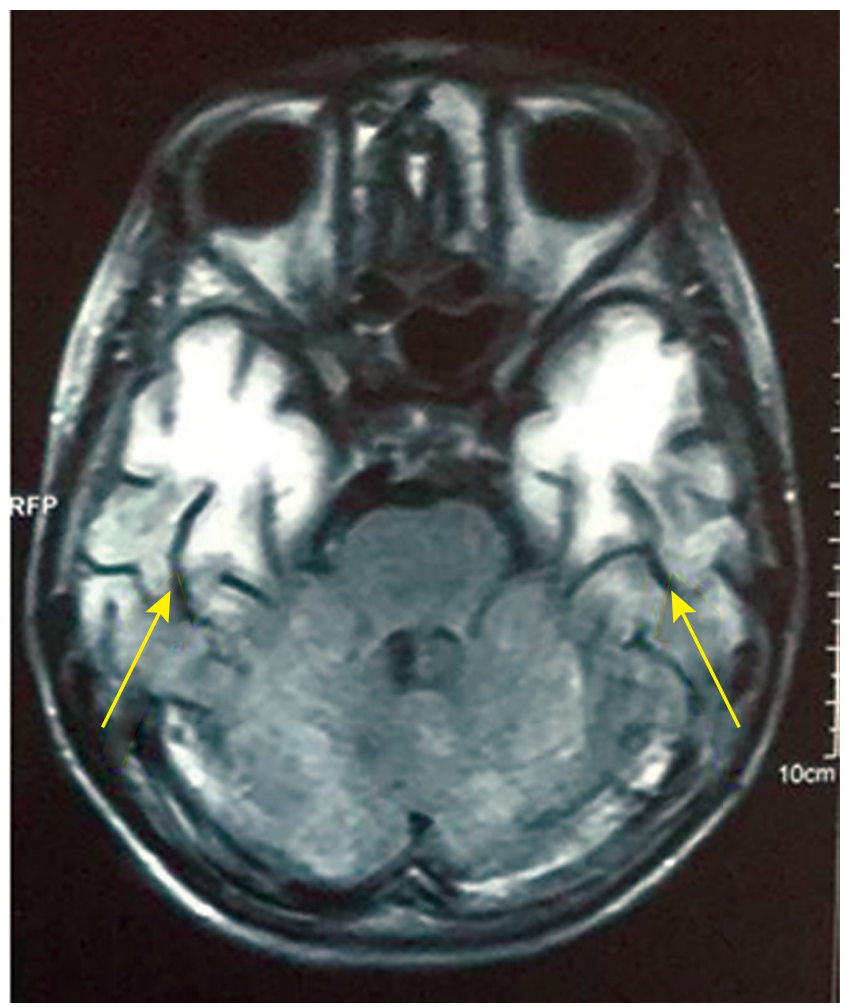

Figure 2. Axial Flair MRI sequence: marked hyperintensities of the anterior temporal lobes.
1. Mignarri A, Arrigucci U, Coleschi P, Bilenchi R, Federico A, Dotti M. Temporal lobe abnormalities in neurosyphilis. Pract Neurol. 2014; 14 (6): 449-50. https://doi.org/10.1136/practneurol-2014-000927
2. Hama K, Ishiguchi H, Tuji T, Miwa H, Kondo T. Neurosyphilis with mesiotemporal magnetic resonance imaging abnormalities. Inter Med. 2008;47 (20): 1813-7.

'Universidade Federal do Rio Grande do Norte, Hospital Universitário Onofre Lopes, Unidade de Distúrbios do Movimento, Natal RN, Brasil. Correspondence: Rodrigo Alencar e Silva; Rua Henri Koster, 1029 / apt.1202; 59015-090 Natal RN, Brasil; E-mail: alencar-rodrigo@hotmail.com Conflict of interest: There is no conflict of interest to declare.

Received 05 November 2016; Received in final form 25 June 2017; Accepted 04 July 2017. 